\title{
The Empirical Case for Specific Performance: Evidence from the IBP-Tyson Litigation
}

\author{
Yair Listokin*
}

Contract scholars debate the relative merits of specific performance and damages, but few studies assess remedies from an empirical perspective. This article examines the stock market response to an unusual specific performance award granted to IBP, Inc. in material adverse change (MAC) clause litigation against Tyson Foods, Inc. The combined value of Tyson and IBP rose after specific performance was granted, implying that specific performance created value. This result contrasts with other papers indirectly showing large decreases in combined market value after damages remedies are awarded. These results suggest that, from a postbreach perspective, the common law's preference for damages may be misplaced. The article identifies a number of settings, such as certain types of MAC clause controversies, wherein the use of specific performance rather than damages should be encouraged.

\section{INTRODUCTION}

What is the appropriate remedy for breach of contract? ${ }^{1}$ Although the common law favors a money damages remedy, ${ }^{2}$ several scholars advocate the

\footnotetext{
*Everett McKinley Dirksen United States Courthouse, 219 S. Dearborn St., Chicago, IL 60604; email: ylistokin@yahoo.com. Law Clerk to the Honorable Richard A. Posner, U.S. Court of Appeals, Seventh Circuit; J.D. Yale 2005; Ph.D. Princeton 2002.

I am very grateful to Ian Ayres, Hon. Guido Calabresi, Daniel Ho, Stephanie Listokin, Jonathan Macey, Roberta Romano, and Alan Schwartz for many insightful comments and suggestions.

'Some of the many articles discussing this issue include William Bishop, The Choice of Rernedy for Breach of Contract, 14 J. Legal Stud. 299 (1985); Lewis Kornhauser, An Introduction to the Economic Analysis of Contract Remedies, 57 U. Colo. L. Rev. 683, 711-17 (1986); Anthony T. Kronman, Specific Performance, 45 U. Chi. L. Rev. 351 (1978); Paul Mahoney, Contract Remedies and Options Pricing, 24 J. Legal Stud. 139 (1995); Timothy Muris, The Costs of Freely Granting Specific Performance, Duke L.J. 1053 (1982); Alan Schwartz, The Case for Specific Performance, 89 Yale L.J. 271 (1979); Thomas S. Ulen, The Efficiency of Specific Performance: Toward a Unified Theory of Contract Remedies, 83 Mich. L. Rev. 341 (1984); Edward Yorio, In Defense of Money Damages for Breach of Contract, 82 Colum. L. Rev. 1365 (1982).

${ }^{2}$ See Oliver Wendell Holmes, The Path of the Law, 10 Harv. L. Rev. 457, 462 (1897) (stating that "the duty to keep a contract at common law means a prediction that you must pay damages
} 
use of specific performance in many circumstances. ${ }^{3}$ Reflecting these pro-specific-performance views, the revised Uniform Commercial Code (UCC) enables specific performance to be stipulated by agreement of the parties. ${ }^{4}$

Clearly, the "right" remedy for breach of contract is not an obvious one. Both damages and specific performance offer several advantages and shortcomings with respect to each other. Specific performance ensures that the promisee receives the full benefit of his or her bargain and that promisors do not breach opportunistically, hoping for damages below the cost of performance. When performance is efficient and damages fall short of the costs of performance, then either the performance fails to occur (underperformance) or the parties must engage in costly bargaining to bring efficient performance to fruition. A specific performance remedy when breach is efficient, however, necessitates costly bargaining to arrive at efficient nonperformance. If bargaining fails, then specific performance causes overperformance. The relative importance of these two concerns-the tendency for underperformance arising from money damages versus increased renegotiation costs and potential for overperformance with specific performance-determine whether specific performance or damages should be the generally preferred remedy.

Given the importance of remedies for contract law, some information regarding the relative size of the two conflicting effects is much needed. Sadly, almost none exists. Little is known about whether specific performance or damage remedies are typically chosen in an efficient manner.

This article offers empirical evidence about the ex-post efficiency of a specific performance award. In the beginning of 2001, Tyson (the largest chicken company in the United States) agreed to acquire IBP (the largest

if you do not keep it-and nothing else"). See also UCC $§ 2-716$ (2005) (limiting the application of specific performance to unique goods or "other proper circumstances").

${ }^{3}$ In a Coasean world with no transactions costs, the remedy will be immaterial from an efficiency perspective-the parties will bargain to the efficient remedy in any case.

${ }^{4}$ See UCC $\$ 2-716(1)$ (proposed revision 2005) (stating that "specific performance may be decreed if the parties have agreed to that remedy"). See also Alan Schwartz, The Myth that Promisees Prefer Supercompensatory Remedies: An Analysis of Contracting for Damage Measures, 100 Yale L.J. 369, 387-89 (1990) (discussing whether contractually specified specific performance should be enforced by the courts). 
beef producer in the United States) to create the "nation's leading protein provider." Tyson subsequently attempted to terminate the acquisition, despite IBP's wish to continue, claiming that some developments in IBP's business violated IBP's warranties and triggered a material adverse change (MAC) clause in the merger agreement. The conflict ended in the Delaware Chancery Court (interpreting New York law). In an important opinion, the Chancery Court rejected Tyson's arguments. ${ }^{6}$ More importantly (for the purposes of this study), the Chancery Court awarded the unusual remedy of specific performance. ${ }^{7}$ Tyson was required to merge with IBP according to the original terms of the agreement. ${ }^{8}$

This article examines the stock market consequences of this event. In a zero-transaction-costs world, the combined values of Tyson and IBP would be unaffected by the decision or the choice of remedy. Before the decision, the market would assume that the efficient performance/nonperformance decision would be reached regardless of the court's ruling. As a result, the court's ruling would not affect the "size of the pie" available to Tyson or IBP, but only the distribution of the pie between the two companies. Following the court's ruling, the winner's value should increase and the loser's should decrease by equal amounts; the combined value of the two companies should remain the same.

In a world with positive transaction costs, however, the Chancery Court's choice of remedy matters. If completion of the merger is the efficient outcome, then specific performance will be the preferred remedy. Damages might be undercompensatory, and bargaining difficulties might preclude an efficient merger if such were not mandated. If damages were high enough, then they also might threaten the financial stability of Tyson, at great cost to the combined value of the two companies. In these contexts, specific performance should raise the combined value of Tyson and IBP by increasing the size of the pie. By contrast, if noncompletion of the merger

\footnotetext{
${ }^{5}$ In re IBP S'holders Litig., 789 A.2d 14, 31 (Del. Ch. 2001) [hereinafter IBP].

${ }^{6} \mathrm{Id}$.

'One law firm described the specific performance remedy as a "very unusual result." Vedder Price Kaufman \& Kamholz, Corporate M\&A Advisor (2001), available at <http://www. vedderprice.com/docs/pub/8e3d6360-ec07-4974-a9c9-0d44ec45bd30_document.pdf. $>$.
}

${ }^{8}$ See $I B P, 789$ A.2d 14. 
is the efficient option, then specific performance should destroy value by compelling the dueling companies to conduct bargaining to avoid merging.

The $I B P$ verdict offers a unique opportunity for studying the efficiency of specific performance. Most commentators surveying the IBP litigation agreed that damages were the most likely remedy. ${ }^{9}$ The market was most likely surprised by the Chancery Court's specific performance award. Moreover, the verdict concerned a question-whether the merger would go forward - that was quantitatively important for the value of both companies, making it unlikely that the effects of the verdict on the companies' combined value would be "lost" in the noise of ordinary stock market fluctuations. Apparently, the surprise specific performance remedy was value maximizing. After the Delaware Chancery Court's ruling and specific performance award, the combined stock market value of Tyson and IBP rose by a statistically significant 5 percent (relative to the market index) within one day of trading. The increase in value persisted after three days, although results are no longer as statistically significant. Tyson and IBP signed a revised agreement to combine shortly after the decision, at terms similar (but slightly more favorable to Tyson) to those in the original contract. ${ }^{10}$ As explained below, the best explanation for the positive market reaction to the decision is that the surprising specific performance award reduced the probability of bargaining breakdowns in a bilateral monopoly setting between two hostile parties and mitigated principal-agent conflicts that might have impeded an efficient merger.

Although the specific performance award in $I B P$ was unusual, it was not unique. For example, the IBPopinion cited a Third Circuit decision that also ruled that specific performance was justified in the context of a MAC clause litigation. ${ }^{11}$ To shed some light on the robustness of the value creation caused by specific performance in MAC litigations, the stock market effects of the Allegheny rulings are also studied. Although the precise questions decided in Allegheny are different than those considered in IBP and the mag-

\footnotetext{
${ }^{9}$ See, e.g., Vedder Price, supra note 7 (describing the remedy as "very unusual"); What You Do Know Can Hurt You, Corporate Control Alert, July 2001, at 12 (quoting a prominent attorney stating that "I don't know of anyone who has ordered two companies to merge").

${ }^{10}$ See Tyson's Trial Tribulations, Corporate Control Alert, July 2001, at 17.

${ }^{11}$ Allegheny Energy, Inc. v. DQE, Inc., 171 F.3d 153 (3d Cir. 1999). See also Allegheny Energy, Inc. v. DQE, Inc., 216 F.3d 1075 (3d Cir. 2000); Allegheny Energy, Inc. v. DQE, Inc., 74 F. Supp. 2d 482 (W.D.P.A. 1999).
} 
nitude and statistical significance of the effects are smaller, the general pattern remains the same-specific performance awards add value. Other remedies destroy value. Apparently, the market expects specific performance to be granted more infrequently than efficiency would dictate and therefore responds positively to surprising specific performance awards.

These findings have potentially important implications for the age-old debate on contract remedies, although the limited sample size precludes any firm conclusions. The common law's preference for money damages should be viewed with heightened suspicion. ${ }^{12}$ At a minimum, the revised UCC's attempts to enhance the availability of stipulated specific performance awards should be encouraged.

The article proceeds as follows. Section II surveys the literature evaluating contract remedies. Section III applies this literature to the IBP-Tyson litigation to establish a context for evaluating the stock market responses to various events over the course of the litigation. Section IV offers an "eventstudy" analysis of the stock market responses to important events in the IBP-Tyson merger. Section $\mathrm{V}$ interprets the findings and assesses their implications for contract law.

\section{Contract Remedies}

\section{A. Theoretical Arguments}

When breach is efficient-when the social surplus created by performance is less than the surplus from breach-accurately calculated money damage awards are superior to specific performance remedies. If damages always equal the harm done to the promisee and courts never make errors in deciding whether a contract has been breached, then a promisor will breach only if the benefits from breaching exceed the harm caused to the promisee (as reflected in the damage awards). In other words, the promisor will breach only when breach is efficient. Several scholars praise damage awards for this

\footnotetext{
${ }^{12}$ More generally, "property rule" protections may be more efficient than commonly realized (and liability rule protections less so). See Guido Calabresi \& A.D. Melamed, Property Rules, Liability Rules and Inalienability: One View of the Cathedral, 85 Harv. L. Rev. 1089 (1976). The $I B P$ case is an unusual setting in which to apply the "Cathedral" and post-Cathedral means of analysis of remedies. The entitlement at stake in Tyson $v$. IBP, IBP's right to sell to Tyson at a given price, is itself a form of "put option." Thus, the IBP-Tyson remedy also falls naturally within the class of "put-option" liability rules described in lan Ayres \& Paul Goldbart, Optimal Delegation and Decoupling in the Design of Liability Rules, 100 Mich. L. Rev. 1 (2001).
} 
feature-by giving the promisor an option to perform or pay damages, damage awards give the promisor the incentive to find the most efficient use of resources, without having to incur the transaction cost of bargaining with the promisee to obtain the promisee's approval. ${ }^{13}$

When damages are not accurately calculated and parties do not bargain costlessly to the efficient result, ${ }^{14}$ however, damage awards give rise to inefficiencies. Under these plausible assumptions, a promisor may breach in spite of the fact that the value of performance to the promisee is greater than the cost of performance to the promisor. The promisor will breach if he or she believes the damages will be less than the costs of performance. In a zero-transaction-costs world, performance will occur even with incorrect damages, as the promisor and promisee will share the surplus from efficient performance in any case. When transaction costs are greater than zero, however, efficient performance may not happen in spite of its efficiency (underperformance). ${ }^{15}$ Failures in bilateral monopoly bargaining resulting from differing valuations, liquidity constraints, spite, and endowment effects may make inefficient nonperformance a likely outcome when performance is not compelled. ${ }^{16}$ Even if efficient performance occurs in spite of these obstacles, a damage remedy necessitates costly bargaining to attain the efficient outcome.

Specific performance mitigates the underperformance problem. By its very nature, specific performance enables the promisee to get the benefit of his or her bargain. ${ }^{17}$ Because specific performance precludes an undercompensatory damage award, it reduces the promisor's incentive to breach when performance is efficient. As a result, a promisor has less incentive to breach opportunistically.

\footnotetext{
${ }^{13}$ See, e.g., Richard Posner, Economics Analysis of Law 130-35 (5th ed. 1998).

${ }^{14} \mathrm{~A}$ finding of no breach when breach has occurred (leading to no damages) is an extreme form of inaccurate damages assessment.

${ }^{15}$ Indeed, the parties have already failed at bargaining - or else trial would not have taken place. Given this initial failure in bargaining, a subsequent bargaining failure appears likely.

${ }^{16}$ For evidence that the efficient result is not always obtained even when the number of parties is small, see Ward Farnsworth, Do Parties to Nuisance Cases Bargain After Judgment? A Glimpse Inside the Cathedral, 66 U. Chi. L. Rev. 373 (1999).
}

${ }^{17}$ Specific performance is also preferred by those who emphasize the moral dimensions of breach as failure to keep a promise. See, e.g., Charles Fried, Contract as Promise (1981). 
Specific performance, however, raises other transaction costs. When breach is efficient, a specific performance award requires additional negotiations to ensure that the optimal performance decision is undertaken. If negotiations fail, then inefficient performance ensues. Fear of these "overperformance costs" may explain why specific performance can be awarded only at the court's discretion under common law. ${ }^{18}$

This analysis suggests a general standard for choosing when to award specific performance versus damages. When the risks of underperformance are greater than the risks of overperformance, specific performance is the preferred remedy because it induces more performance and lowers transaction costs. When the risks of overperformance are greater, then damages are the better remedy because they prevent inefficient performance and reduce associated transaction costs.

MAC provisions may be especially prone to cause underperformance problems when bargaining is imperfect. As explained by Gilson and Schwartz, ${ }^{19}$ the purpose of MAC provisions is to mitigate underinvestment by the seller in a merger agreement during the postsigning/preclosing period. The MAC clause mitigates the underinvestment problem by allowing the buyer to exit the deal (and thereby hurting the seller) if certain material adverse changes occur. Because underinvestment raises the probability of the occurrence of a material adverse change, the MAC clause raises the incentive of the seller to invest and thereby lowers the probability that the MAC will be exercised.

MAC clauses mitigate underinvestment problems, but they raise the risk of underperformance when bargaining is imperfect. Gilson and Schwartz explain that, as a general matter, endogenous merger risk should be placed on the seller and exogenous risk on the buyer. ${ }^{20}$ Because MACs are written as standards and not as rules and are necessarily incomplete, buyers may exploit MACs to renege on merger agreements that have become unprofitable for the buyer due to exogenous changes in the value of the

\footnotetext{
${ }^{18}$ The revised UCC (yet to be adopted by any state) enables the parties to a contract to stipulate specific performance. See Rev. UCC $\$ 2-716(1)$.

${ }^{19}$ See Ronald Gilson \& Alan Schwartz, Understanding MACs: Moral Hazard in Acquisitions (2004), available at $\langle$ http://ssrn.com/abstract $=515105\rangle$. Note that Gilson and Schwartz assume costless renegotiation. As a result, some of their conclusions differ from the ones made here.

${ }^{20}$ See Gilson \& Schwartz, supra note 19, at 29.
} 
combined companies-in spite of the fact that insuring the buyer against such exogenous risk is not the purpose of the MACs. ${ }^{21}$ When bargaining and courts are imperfect, the MAC, which terminates the deal, thus raises the possibility of underperformance. In addition to the possibility of inadequate damages, the MAC introduces the possibility of inadequate contract enforcement due to the difficulties of interpreting MACs properly. Thus, MAC clause litigation may be particularly conducive to specific performance remedies. ${ }^{22}$

In IBP, the Delaware Chancery Court concluded that Tyson had assumed the exogenous risk of the merger but was attempting to use the MAC clause to exit the merger because a postagreement cyclical downturn in the beef industry had reduced IBP's value..$^{23}$ The Chancery Court noted that the "notion that the [MAC clause] gave Tyson a right to walk away simply because of a downturn [in the industry] is untenable." ${ }^{24}$ The Chancery Court emphasized that the CEO of Tyson had stated that Tyson was purchasing IBP "fully aware of the cyclical factors that affect commodity meat products." 25 Although the court focused on other factors in finding that the MAC clause was inapplicable, the court's reasoning suggests that Tyson was attempting

\footnotetext{
${ }^{21}$ Buyers might also threaten to call the MAC as a way of expropriating the seller's deal-specific investments. When courts are imperfect and MACs are vaguely worded, a seller must be concerned about the possibility of such holdups.

${ }^{22}$ This analysis implies a risk of underperformance when the buyer wins as well as when the buyer loses. To mitigate this risk, a "spur" type of entitlement might be appropriate when the buyer has successfully exercised the MAC clause. That is, when a buyer successfully exercises MAC, the court should still compel a merger, but allow the seller to force a sale to the buyer at a price lower than the one set out in the merger agreement. Alternatively, the buyer should be allowed to press for specific performance rather than damages if it improperly exercised the MAC. As one commentator noted, "IBP . . could be cited by buyers finding themselves in situations similar to Tyson's even where the seller is seeking monetary damages. A buyer could argue that it should be permitted to back out of a deal under the terms of the contract and that, in the alternative, if the court determined that it does not have the right to walk away, then specific performance should be the remedy." M\&A Law., July 2001/August 2001, at 19 .
}

${ }^{23}$ See $I B P, 789$ A.2d at 47. For an extensive theoretical analysis of the IBP remedy, see Jordan A. Goldstein, The Efficiency of Specific Performance in Stock-for-Stock Mergers, 29 Del. J. Corp. L. 747 (2005).

${ }^{24} I B P, 789$ A.2d at 66.

${ }^{25}$ Id. at 45 (quoting John Tyson, CEO of Tyson). 
to place exogenous risk on IBP. ${ }^{26}$ As a result, the Chancery Court ruled that the merger agreement remained binding.

Instead of the damage remedy the market was apparently expecting, the Chancery Court concluded that IBP was entitled to specific performance. ${ }^{27}$ At first glance, the Chancery Court's grant of specific performance to IBP epitomizes the dangers of specific performance inducing overperformance. What could be more value destroying than forcing two hostile management teams to merge their firms together? ${ }^{28}$ In spite of this concern, the Chancery Court ruled that specific performance was warranted because of the difficulty of measuring damages accurately. ${ }^{29}$ Furthermore, the Chancery Court noted that Tyson was still considering purchasing IBP at a lower price and that Tyson's posttrial briefs failed to oppose specific performance as a remedy, suggesting that a merger was not practically impossible. ${ }^{30}$

The Chancery Court's reasoning may be interpreted in the context of the theoretical framework just developed. First, the Chancery Court felt that Tyson was inappropriately attempting to reassign exogenous risk by exercising the MAC. Second, the Chancery Court was concerned about misestimation of damages. Third, the Chancery Court found no evidence that the underlying logic of the merger had been changed by the downturn in the industry. All these factors suggest that underperformance was a risk if

\footnotetext{
${ }^{26}$ Note that, unlike many MAC provisions, the ones at issue in Tyson did not include a long list of exclusions that attempted to place exogenous risk on the buyer. As a result, Gilson and Schwartz conclude that the Delaware Chancery Court's interpretation of the MAC in Tyson was mistaken. See Gilson \& Schwartz, supra note 19, at 44-45. Gilson and Schwartz also criticize the Chancery Court's lack of emphasis on the endogenous versus exogenous risk question. The positive stock market reaction, however, suggests that the Chancery Court may have reached the right result and assignment of risks for the wrong reasons. The Chancery Court's remedy, however, was chosen deliberately and correctly.

${ }^{27}$ See supra note 9 .

${ }^{28}$ Chancellor Strine recognized this concern. See IBP, 789 A.2d at 83 . Chancellor Strine noted, however, that once Tyson acquired IBP, it would be able to fire IBP management in the event of difficulties. Id.

${ }^{29}$ IBP, 789 A.2d at $83-84$.

${ }^{30}$ Id. at 82 . As the court noted, too much should not be read into this point. Tyson's briefs never stipulated that specific performance was the appropriate remedy, nor did the briefs discuss any other remedy. Thus, it is not clear that Tyson was satisfied with a specific performance remedy in the event it failed to win the litigation.
} 
bargaining was imperfect. The original logic of the merger remained. To mitigate the risks of underperformance and minimize bargaining costs, the Chancery Court chose specific performance. ${ }^{31}$ Was the Chancery Court's reasoning sound? The next section evaluates the stock market's verdict on the Chancery Court's decision. Before presenting the results of this study, it is important to examine the current state of the empirical evaluation of remedies literature. This discussion provides some necessary context for the data analysis that follows.

\section{B. Empirical Evaluation of Remedies}

No studies directly evaluate the efficiency of different remedies. Several papers, however, examine the effects of litigation on valuation as a more general matter. The results of these studies shed some light on the efficacy of various remedies. Two prominent examples are the studies of the TexacoPennzoil litigation conducted by Cutler and Summers and by Engerman and Cornell. ${ }^{32}$ In this litigation, Pennzoil won a multibillion dollar damage award from Texaco. Cutler and Summers examine the combined stock market value reaction to the large damage award and find that the combined value of the companies declined drastically. They attribute this "leakage" of value to the costs of financial distress-although at first glance a damage award simply redistributes value from one party to another, the large size of the damage award raised the specter of bankruptcy for Texaco. This harmed Texaco's relationships with many third parties, and apparently caused the decline in combined valuation. Similar leakages of value as a result of financial distress have been found in other studies of intercorporate litigation. ${ }^{33}$

What these studies do not mention is that the leakage in value is potentially the result of the choice of remedy. If large damage awards had not

\footnotetext{
${ }^{31}$ Even if the parties would have ultimately merged at an alternative price, specific performance obviated the need for extended haggling over the revised terms of the deal.

${ }^{32}$ David M. Cutler \& Lawrence H. Summers, The Costs of Conflict Resolution and Financial Distress: Evidence from the Texaco-Pennzoil Litigation, 19 Rand J. Econ. 157 (1998); Kathleen Engerman \& Bradford Cornell, Measuring the Costs of Corporate Litigations: Five Case Studies, 17 J. Legal. Stud. 377 (1988).
}

${ }^{33}$ See Sanjai Bhagat, John Bizjak \& Jeffrey Coles, The Shareholder Wealth Implications of Corporate Lawsuits, 27 Fin. Mgmt. 5 (1998); Sanjai Bhagat, James A. Brickley \& Jeffrey Coles, The Wealth Effects of Interfirm Lawsuits: Evidence from Corporate Lawsuits, 35 J. Fin. Econ. 221 (1994). Note that many of the results found in these studies concern the wealth effects of the announcement of intercorporate lawsuits rather than the wealth effects of verdicts. 
been required, the defendants might not have suffered financial distress and value would not have been destroyed. ${ }^{34}$ Thus, money damages, often considered the simplest and cheapest type of remedy, cause substantial loss of value in some contexts. But we should not be too hasty to criticize damages as a remedy; perhaps leakage is simply an inevitable cost of a plaintiff victory at trial. If the cost of performance exceeds the cost of damages, then damages should lead to no more financial distress than specific performance remedies. ${ }^{35}$

One explanation for the scarcity of studies on the impact of remedies may be the relative rarity of decisions causing large changes in stock market valuations. Without large changes in value, the event-study methodology employed in such papers will be incapable of uncovering any effect of remedies-if there is no event, there can be no event study. To illustrate, suppose two publicly traded companies go to court over a contract with a value of $\$ 10,000$. Suppose further that a court imposes an inefficient specific performance remedy, which causes a decrease in value of $\$ 5,000$. In this case, the decision should cause a decrease in combined value of $\$ 5,000$ for the two companies. Given the standard "noisy" fluctuations in stock prices, however, such a small effect on the combined value will be imperceptible. A study of this event would probably conclude that the specific performance verdict has no impact on combined value, in spite of the remedy's inefficiency. ${ }^{36}$

\footnotetext{
${ }^{94}$ This consideration is particularly relevant with respect to Texaco and Pennzoil. In this litigation, the damages imposed on Texaco far exceeded most estimates of the benefit of performance to Pennzoil. As a result, specific performance, unlike damages, would not have threatened financial distress to nearly the same degree.
}

${ }^{35}$ There is no doubt that damages estimation is more uncertain than specific performance. As a result, damages may be more likely to lead to outsize remedies that threaten the defendant's existence. For example, many scholars consider the damages award determined by the jury in the Texaco-Pennzoil litigation to be flawed and overly generous. See Cutler \& Summers, supra note 32 , at $158-59$. Specific performance would have mitigated the value-destroying financial distress caused by the excess generosity of the jury's damages award.

${ }^{36}$ This concern helps explain the emphasis placed upon the Texaco-Pennzoil case studies conducted by Summers and Cutler, supra note 32 and Engermann and Cornell, supra note 32, which are frequently cited for the proposition that financial distress destroys value, in spite of the difficulty of generalizing from a single case study. See, e.g., Bhagat et al., supra note 33. The Texaco-Pennzoil litigation caused large fluctuations in the value of both companies. Consequently, changes in the combined value of both companies can be identified more plausibly than in other cases with smaller stakes. 


\section{How to Evaluate the Stock Price Reaction to the Delaware Chancery Court's Decision}

Without evidence on the impact of specific performance on stock market valuations, a thorough empirical assessment of specific performance and damages is impossible. The IBP-Tyson merger litigation offers an unusually straightforward window for evaluating specific performance in action. Because the merger was a high-stakes event for both companies, decisions concerning the merger caused large fluctuations in stock prices, thereby facilitating the identification of the efficiency of specific performance.

The Chancery Court felt that specific performance was the appropriate remedy in IBP, but the court may well have been wrong. The stock market, however, is unlikely to have systematic biases in favor of one remedy over another. ${ }^{37}$ The Chancery Court's decision yielded two pieces of information to the market, namely, (1) that IBP won the litigation, and (2) that the remedy would be specific performance. The first piece of information should cause the value of IBP to go up and the value of Tyson to go down, but should not lead to any change in the combined value of the two companies-it concerns the distribution of the "pie" (the pie being the total value of the two companies) rather than the size of the pie. The second piece of information, however, affects the size of the pie. In a world with costly bargaining, specific performance raises the probability of a merger and lowers the probability of a large damages payment. If the market concludes that this change in probabilities raised the expected profit streams from the two companies, then the combined values of the two companies should rise. If these changes destroyed value-a plausible assumption given the nature of the forced merger and the general trend toward "leakage" of value after plaintiff victories in intercorporate litigation-then the stock market response should be negative.

To better understand the impact of the $I B P$ verdict on the combined value of IBP and Tyson, I have developed a simple model of the stock market response to the Delaware Chancery Court's specific performance decision.

\section{A. Variables}

Let $V_{T}^{B D}$ and $V_{I}^{B D}$ be the total stock market values of Tyson and IBP, respectively, before the decision is made. Let $V_{T}^{A D}$ and $V_{I}^{A D}$ be the total stock market

\footnotetext{
${ }^{37}$ According to the efficient-markets hypothesis, the stock market will efficiently value the change in expected profit streams caused by the decision and alter the value of Tyson and IBP accordingly.
} 
values of Tyson and IBP, respectively, after the decision is made. Let $V_{T, S P}$ and $V_{I, S P}$ be the values of Tyson and IBP, respectively, if specific performance (a required merger) is imposed on the two companies and let $V_{T, N S P}$ and $V_{I, N S P}$ be the values of Tyson and IBP (exclusive of damages), respectively, if specific performance is not imposed. ${ }^{38}$ This highlights the fact that both a Tyson victory and an IBP victory with a damages award allocate similar bundles of rights-absent further negotiation, Tyson and IBP will not merge under either decision. If Tyson wins, its total value is $V_{T, N S P}$. A Tyson victory and an IBP victory with a damage award differ in a distributional sense. Tyson will be worth less and IBP worth more if the court rules for IBP because of the impact of the damage payment. Thus, let $D_{T}$ be the cost of a damage award to Tyson and let $D_{I}$ be the value of a damage award to IBP. If Tyson loses the litigation and is forced to pay damages, its value is $V_{T, N S P}-D_{T}$ - the only difference between this value and Tyson's value if it wins is the requirement to pay damages of $D_{T}$. Finally, let $\alpha_{T}$ be the probability that Tyson wins at trial (i.e., the court finds no breach of contract). The Chancery Court's acknowledgment that the question was a close one suggests that $\alpha_{T}$ should be near 0.5 . Let $q_{D}$ be the probability that the court will award damages, given that it finds for IBP. Given the common-law preference for damages rather than specific performance, $q_{D}$ should be high (near one) ${ }^{39}$

The value of Tyson and IBP on the day before the decision is a weighted average of the value of each company under any of the decision possibilities. Thus arise the equations set out in the next subsection.

\section{B. Stock Market Valuations}

$$
\begin{aligned}
& V_{T}^{B D}=\alpha_{T} V_{T, N S P}+\left(1-\alpha_{T}\right)\left[q_{D}\left(V_{T, N S P}-D_{T}\right)+\left(1-q_{D}\right) V_{T, S P}\right] \\
& V_{I}^{B D}=\alpha_{T} V_{I, N S P}+\left(1-\alpha_{T}\right)\left[q_{D}\left(V_{I, N S P}+D_{I}\right)+\left(1-q_{D}\right) V_{I, S P}\right]
\end{aligned}
$$

After the decision, the market's uncertainty is resolved. The market no longer has to account for the possibility of a Tyson victory or an IBP victory with a damages award. The values are thus:

\footnotetext{
${ }^{38}$ This model assumes that the probability of a Type 4 decision-a Tyson victory coupled with a forced merger-was near zero. Given the rarity of such decisions, this appears to be a plausible assumption.

${ }^{39}$ Recall that the specific performance remedy was described as "very unusual." See Vedder Price, supra note 7.
} 


$$
\begin{aligned}
& V_{T}^{A D}=V_{T, S P} \\
& V_{l}^{A D}=V_{l, S P} .
\end{aligned}
$$

The change in the combined stock market value as a result of the decision is:

$$
\begin{aligned}
& \left(V_{T}^{A D}+V_{I}^{A D}\right)-\left(V_{T}^{B D}+V_{I}^{B D}\right)=\left(\alpha_{T}+q_{D}-\alpha_{7} q_{D}\right)\left[\left(V_{T, S P}+V_{I, S P}\right)-\left(V_{T, N S P}+V_{I, N S P}\right)\right] \\
& \quad+\left(q_{D}-\alpha_{T} q_{D}\right)\left[D_{T}-D_{I}\right] .
\end{aligned}
$$

\section{What the Stock Price Movements Tell Us}

Equation (1) is the primary quantity of interest in the empirical analysis below. Note that in a Coasean-no-transactions-cost world, $\left(V_{T, S P}+V_{l, S P}\right)=$ $\left(V_{T, N S P}+V_{I, N S P}\right)$ because the parties will bargain costlessly around the court's decision to arrive at the efficient result. Moreover, $D_{T}=D_{l}$, the cost of the damages award to Tyson, is the same as the benefit of the damages award to IBP. Therefore, in a Coasean world the combined value of Tyson and IBP should be unchanged by the verdict.

When transactions costs are nonzero, the verdict matters for the combined value of the two companies. An increase in the combined value after the merger reflects the market's opinion that the value of the two companies is greater when specific performance is dictated than under other outcomes. The combined values of the two companies will tend to rise after a specific performance remedy if $\left(V_{T, S P}+V_{l, S P}\right)>\left(V_{T, N S P}+V_{l, N S P}\right)$. This inequality will hold if the merger is the efficient outcome. When the merger is efficient, specific performance precludes bargaining failures that may foil the merger if the merger is not required. Alternatively, specific performance economizes on transaction costs that must follow a damages award in order for the parties to renegotiate a merger. In addition, the specific performance award will tend to increase value if $D_{T}>D_{I}$. If the cost of the damages award to Tyson is greater than the value of the damages award to IBP, then specific performance will raise value by avoiding the value destroying damages award. The costs and benefits of damages awards will tend to diverge when a firm's financial position is placed at risk by damages awards but not by performance. As explained below, these conditions are unlikely to apply in the IBP-Tyson context. Thus, an increase in combined stock value is best explained by an increase in the probability of an efficient merger.

When a nonmerger is the efficient outcome, by contrast, specific performance raises the possibility of overperformance and requires additional negotiations. Thus, the combined stock price will tend to decline after a spe- 
cific performance award if nonmerger is the efficient outcome because $\left(V_{T, S P}\right.$ $\left.+V_{l, S P}\right)<\left(V_{T, N S P}+V_{I, N S P}\right)$, making Equation (1) more likely to be negative.

Finally, note that the changes in individual and combined stock market value after the decision will be higher when $q_{D}$ is higher, other things equal. Large postdecision changes in value for Tyson and IBP will provide some evidence for the assertion that the specific performance remedy was a surprise to the market.

\section{Data Analysis AND Interpretation}

\section{A. Market Response to Events in the Tyson-IBP Litigation}

To examine the stock market response to specific performance, the event study focuses on specific performance verdicts relating to merger activity between two publicly traded companies. Mergers and acquisitions are typically high-stakes events, causing large fluctuations in the market value of the companies involved. Extensive searches on the Lexis-Nexis and Westlaw databases revealed only two cases mentioning specific performance in the context of merger litigation verdicts. These cases are IBP and Allegheny. ${ }^{40} \mathrm{Of}$ these two cases, only the $I B P$ verdict ruled on both the merits of the opposing parties' arguments and the appropriate remedy on the same date. ${ }^{41} \mathrm{Con}-$ sequently, the IBP verdict should cause larger stock price fluctuations, thereby facilitating identification of specific performance's efficiency.

Data on Tyson and IBP stock prices and market valuations was obtained from CRSP. The responses of the separate valuations, as well as the combined valuation of the two companies, were examined in relation to important events concerning the merger and the subsequent litigation. The "events" are as follows. ${ }^{42}$

\footnotetext{
${ }^{40}$ See IBP, 789 A.2d 14; Allegheny Energy, Inc. v. DQE, Inc., 171 F.3d 153 (3d Cir. 1999).

${ }^{41}$ Compare IBP, 789 A.2d 14 with Allegheny Energy, Inc. v. DQE, Inc., 171 F.3d 153 (3d Cir. 1999); Allegheny Energy, Inc. v. DQE, Inc., 216 F.3d 1075 (3d Cir. 2000); Allegheny Energy, Inc. v. DQE, Inc., 74 F. Supp. $2 d 482$ (W.D.P.A. 1999).

${ }^{42}$ Each event date is the first market trading day in which the information was available. This information was obtained by reading through Chancellor Strine's opinion, news accounts of the trial, and comparing the dates listed there with market trading days (in some cases, the first news available to the market became available on weekends, so the event date is the Monday following the release of the information). On each event date, trading volumes in both company's shares were extremely high, suggesting that important new information was available to the market.
} 
1. On March 29, 2001, the market learned that Tyson terminated its merger agreement with IBP, claiming that IBP had violated the merger agreement by not disclosing some accounting irregularities at an IBP subsidiary, and requesting damages from IBP. IBP countersued in the Delaware Chancery Court, seeking specific performance of the merger agreement. ${ }^{43}$

2. On June 18,2001 , the market learned of the Delaware Chancery Court's decision that the merger agreement was binding on Tyson and that IBP was entitled to specific performance. ${ }^{44}$

3. On June 28,2001 , the two parties signed a revised merger agreement for terms slightly more favorable to Tyson than the original merger agreement. ${ }^{45}$

The analysis focuses on the Chancery Court's June 18 decision, which bears most directly on the efficiency of specific performance in this context.

Table 1 presents the individual and combined stock market abnormal returns in response to these events. The abnormal returns and standard errors presented in parentheses in Table 1 are calculated according to standard event-study methodology. ${ }^{46}$ The efficient-market hypothesis suggests that the one-day abnormal returns are the best measure of the effects of the litigation.

Because Tyson's pursuit of IBP unfolded over a relatively long period of time, there is no one obvious event date on which to examine the stock market's opinion of the initial merger between Tyson and IBP. Although

\footnotetext{
${ }^{43}$ See $I B P, 789$ A.2d at 51.

${ }^{44}$ See Tyson's Trial Tribulations, supra note 10 , at $13-17$.

${ }^{45}$ Id. at 17 .
}

${ }^{46}$ For discussions of this methodology, see Sanjai Bhagat \& Roberta Romano, Event Studies and the Law: Part I: Technique and Corporate Litigation, 4 Am. L. Econ. Rev. 141 (2002) [hereinafter Bhagat \& Romano I]; Sanjai Bhagat \& Roberta Romano, Event Studies and the Law: Part II: Empirical Studies of Corporate Law, 4 Am. L. Econ. Rev. 380 (2002). The statistical market model forming the basis of the study was calculated using the 100-trading-day period that ended 30 days before the announcement of the first takeover bid for IBP. See Bhagat \& Romano I, at 146-47. Because of the likelihood of covariance between the abnormal return of Tyson and that of IBP during the litigation period, the standard errors of the abnormal returns for the combined value of Tyson and IBP were calculated treating Tyson and IBP as the components of a single portfolio. The standard errors of the abnormal returns listed in the "combined value" columns of Table 1 are the standard errors of the abnormal return for this portfolio. See A. Craig MacKinlay, Event Studies in Economics and Finance, 35 J. Econ. Lit. 13, 27 (1997). 
Table 1: Stock Price Effects of IBP-Tyson Litigation Events

\begin{tabular}{|c|c|c|c|c|c|c|}
\hline \multirow[b]{2}{*}{ Event } & \multicolumn{3}{|c|}{$\begin{array}{c}\text { 1-Day Abmormal Return } \\
\text { Expressed as a Percentage of } \\
\text { Initial Value (Standard Errors } \\
\text { in Parentheses) }\end{array}$} & \multicolumn{3}{|c|}{$\begin{array}{c}\text { 3-Day Abnormal Retum } \\
\text { Expressed as a Percentage of } \\
\text { Initial Value (Standard Errors } \\
\text { in Parentheses) }\end{array}$} \\
\hline & Tyson & $I B P$ & $\begin{array}{c}\text { Combined } \\
\text { Value }\end{array}$ & Tyson & $I B P$ & $\begin{array}{l}\text { Combined } \\
\text { Value }\end{array}$ \\
\hline $\begin{array}{l}\text { 1. Tyson announces it is } \\
\text { reneging (March 29, } \\
\text { 2001) }\end{array}$ & $\begin{array}{l}16.8^{*} \\
(2.7)\end{array}$ & $\begin{array}{r}-28.4^{*} \\
(2.5)\end{array}$ & $\begin{aligned}-5.2^{*} \\
(2.1)\end{aligned}$ & $\begin{array}{l}15.9^{*} \\
(8.1)\end{array}$ & $\begin{array}{r}-36.1^{*} \\
(7.5)\end{array}$ & $\begin{array}{l}-8.6 \\
(6.3)\end{array}$ \\
\hline $\begin{array}{l}\text { 2. DE Chancery Court } \\
\text { decision (June } 18,2001 \text { ) }\end{array}$ & $\begin{array}{r}-17.4^{*} \\
(2.7)\end{array}$ & $\begin{array}{l}33.2^{*} \\
(2.5)\end{array}$ & $\begin{array}{r}4.6^{*} \\
(2.1)\end{array}$ & $\begin{aligned}-15.3 \\
(8.1)\end{aligned}$ & $\begin{array}{l}32.9 * \\
(7.5)\end{array}$ & $\begin{array}{c}5.4 \\
(6.3)\end{array}$ \\
\hline $\begin{array}{l}\text { 3. Tyson and IBP announce } \\
\text { a merger }\end{array}$ & $\begin{array}{c}3.2 \\
(2.7)\end{array}$ & $\begin{array}{c}3.3 \\
(2.5)\end{array}$ & $\begin{array}{c}3.3 \\
(2.1)\end{array}$ & $\begin{array}{c}4.3 \\
(8.1)\end{array}$ & $\begin{array}{c}4.0 \\
(7.5)\end{array}$ & $\begin{array}{c}4.2 \\
(6.3)\end{array}$ \\
\hline
\end{tabular}

NoTE: Each cell in the table presents the "abnormal" percentage change in stock market value (as a percentage of initial value) of Tyson, IBP, or the combined value of Tyson + IBP on the event dates listed in the first cell of each row. The first group of numerical cells in each row presents the abnormal return on the first day after the event. The second group of numerical cells gives the cumulative abnormal return three days after the event. The standard error of each estimate is presented in parentheses below the estimate. The abnormal returns and standard errors are estimated using the "market model" described in Bhagat and Romano I (see note 46). An asterisk indicates that the estimate is significant at the 95 percent level.

long horizons are exceedingly difficult to examine using the event-study methodology, ${ }^{47}$ the combined stock market performance of Tyson and IBP during the premerger-announcement period hints that the merger was effcient. Over the three-month period that culminated in the announcement of the IBP-Tyson merger, the combined value of Tyson and IBP rose by 37 percent. Over this same period, the Dow Jones Industrial Average declined by 1.7 percent.

When Tyson announced the termination of the merger agreement, the prices of Tyson and IBP moved in dramatically different directions. On the first trading day with information about termination, Tyson's value rose by almost 17 percent, whereas IBP's value fell by more than 28 percent. IBP's three-day fall in value was an even more dramatic 36 percent. The large changes in value for each company indicate that the market was surprised by the termination of the merger. Clearly, the market was pleased that Tyson was exiting the deal, and unhappy that IBP might no longer fetch a high

\footnotetext{
${ }^{47}$ See Bhagat \& Romano I, supra note 46 , at $150-51$.
} 
price. The combined value of the two companies fell by a statistically significant 5.2 percent on the day of the announcement and by a total of 8.6 percent in the first three trading days after the termination of the agreement. The cause of this decline in combined value is less clear, and will be discussed below.

After Chancellor Strine ruled for IBP and awarded specific performance, the value of Tyson decreased by a statistically significant 17 percent and the value of IBP rose by more than 33 percent. Again, the dramatic changes in value indicate that the decision and choice of remedy yielded new and surprising information to the market. Note the inverse relationship between these stock market responses and those following Tyson's termination of the merger agreement. The magnitudes of the stock prices' movements are very similar on both days, but the directions of the price movements are reversed. Apparently, whatever was lost or gained by Tyson's decision to terminate the merger was unwound by specific performance. Tyson's value apparently decreased because of the market's dismay that it would have to pay a high price for IBP. Conversely, the market was enthused at the high price that IBP would receive on account of the decision.

Most surprisingly, the combined value of Tyson and IBP rose by a statistically significant 4.6 percent on the day of the decision and by 5.4 percent over a three-day window. ${ }^{48}$ Again, this is a near inversion of the combined value's response to the termination of the merger. In a Coasean world, these responses should not have occurred. Although the events under study will change the distribution of value between the two companies, the efficient outcome should occur through bargaining regardless of the allocation of rights, leading to no change in the combined value. The statistically significant responses of the combined values of the stock to these events strongly refute the Coasean prediction.

The increase in value following the Chancery Court's decision implies that the stock market viewed IBP's victory and the imposition of specific performance in a positive light (relative to the possibility of a Tyson victory or an IBP victory with a damages award) and the companies' combined value rose accordingly. ${ }^{49}$ The model above suggests two reasons for the increase.

\footnotetext{
${ }^{48}$ The three-day estimated rise of 5.4 percent is not significant at the 95 percent level due to the higher standard errors associated with estimates over this extended timeframe.

${ }^{49} \mathrm{Because}$ there were (at least) three possible litigation outcomes (Tyson victory, IBP victory with damages, IBP victory with specific performance), it may be that specific performance was
} 
First, the combined value could increase because of a change in the probability of an efficient merger or a reduction in the transactions costs associated with merging. ${ }^{50}\left(V_{T, S P}+V_{I, S P}\right)>\left(V_{T, N S P}+V_{I, N S P}\right)$. Second, the combined value could increase because of the reduction of the probability that Tyson would be forced to make a large damages payment that caused valuedestroying financial distress ${ }^{51}$-implying that $D_{T}>D_{I}$. Note that both these explanations suggest that specific performance is a superior remedy to damages. Whatever the explanation, the market preferred specific performance to damages.

It is unlikely that value-destroying financial distress would result from a damages award in this context. Value-destroying financial distress occurs when a company's equity cushion is reduced to a small enough level to threaten insolvency. For example, in the Texaco-Pennzoil litigation, the damages award of almost $\$ 12$ billion awarded to Pennzoil exceeded the value of Texaco's equity ( $\$ 8.5$ billion) before the litigation was filed. Clearly, the damages award imposed on Texaco was sufficient to place Texaco in financial distress. ${ }^{52}$ The same cannot be said regarding the IBP-Tyson litigation, however. The difference between IBP's value under the merger contract and its lowest value after Tyson terminated the merger agreement was approxi-

preferable to only one of the other outcomes. Note, however, that the difference between the other two outcomes is merely distributional-the firms are under no obligation to merge in either case. As a result, it is unlikely that the combined value of the two firms would vary greatly depending on whether Tyson won or IBP won and damages were awarded. The critical question for the combined valuations of the two firms was the choice of remedy. The individual valuations, of course, do vary depending on the outcome of the litigation.

${ }^{50}$ But perhaps the combined value increased simply because the market was relieved that IBP won the litigation rather than the choice of remedy. This hypothetical must be developed further to make any sense. Why would an IBP victory in and of itself matter for the combined value of the two firms? Without more, victory just concerns the distribution of the pie rather than the size of the pie. Only if an IBP victory led to some result that increases the size of the pie should the combined value increase.

${ }^{51}$ Another possibility is that the decision reduced the uncertainty surrounding the two firms. Because the trial was expedited, however, the market could not have been surprised to receive a decision. Thus, the uncertainty explanation must hinge on the presumption that uncertainty is reduced more by specific performance than by damages.

${ }^{52}$ See also Bhagat, Brickley \& Coles, supra note 33, at 233-42 (showing that the costs of litigation are higher when the defendant is in greater financial distress). 
mately $\$ 1.4$ billion.$^{53}$ At the time of the court's decision, Tyson's value was more than $\$ 2.5$ billion. Under almost any conceivable damages award, Tyson would have retained a significant equity cushion. Furthermore, under specific performance, Tyson's offer (which allowed IBP shareholders to exchange their shares for cash $)^{54}$ also needed to be financed. The fact that the market did not impose a financial distress penalty on the combined value of the two firms at the time of the merger also suggests that Tyson had ample cushion to finance the acquisition. If Tyson had enough of a cushion to finance the acquisition at a high price without experiencing a large financial distress penalty, then Tyson also was likely to be able to finance a damages award payment without undergoing undue financial distress. ${ }^{55}$ Finally, the market price of Tyson debt was hardly affected by events related to the merger litigation. On the first day of trading following the Chancery Court's decision, the value of one Tyson unsecured note ${ }^{56}$ changed by only 0.03 percent, strongly suggesting that the bond market did not view the Chancery Court's decision as a reprieve from financial distress.

This analysis (and the inverse symmetry of the stock price movements between the termination of the merger and the specific performance award) suggests that the increase in stock market value is most likely the result of an increase in the probability of a value-enhancing merger. Moreover, the market response to the events in the IBP-Tyson saga follows the general tendencies for mergers and acquisitions as uncovered by several studies. ${ }^{57}$ These

\footnotetext{
${ }^{53}$ The market value of IBP, of course, included the potential that IBP would win the litigation. Thus, damages could have been even higher that $\$ 1.4$ billion. Note, however, that Tyson's value included the possibility that it might lose the litigation. Thus, the value of its assets (without any claims by IBP) was greater than $\$ 2.5$ billion.
}

${ }^{54}$ See $I B P, 789$ A.2d at 40.

${ }^{55}$ Specific performance precluded the possibility of an egregious damages award. Because the case was before a judge in the Delaware Chancery Court rather than a jury, the chance of an egregiously high damages award was probably reduced. As a result, it is unlikely that the market was greatly concerned about the possibility of an egregious damages award that would be sufficiently high to threaten Tyson's solvency.

${ }^{56}$ The price of Tyson's unsecured 6.75 percent coupon-rate notes (CUSIP No. 902494AA1) went from $\$ 98.49$ on June 15 to $\$ 98.52$ on June 18 .

${ }^{57}$ See, e.g., Gregg Jarrell, James A. Brickley \& Jeffrey M. Netter, The Market for Corporate Control: The Evidence Since 1980, 2 J. Econ. Perspectives 49 (1988); Elazar Berkovitch \& M.P Narayanan, Motives for Takeovers: An Empirical Investigation, 28 J. Fin. \& Quantitative Analysis 347 (1993). 
studies typically find an increase in value to the target, a decrease in value for the acquirer, and an increase in combined value. This pattern is often interpreted to mean that mergers and acquisitions increase value.

Specific performance raised the probability of an efficient merger (mitigating underperformance problems) for several reasons. Tyson and IBP confronted a bilateral monopoly bargaining problem. Both parties had undertaken investments specific to the merger that could not be recouped if the merger failed to go forward. It is well known that bilateral monopoly bargaining problems often do not end in efficient solutions. ${ }^{58}$ This particular bilateral bargaining problem would be particularly unlikely to end with efficient cooperation. The fact that Tyson and IBP chose to settle their differences in court rather than through negotiations suggests that each party's view of its rightful share of the total surplus differed substantially from the other side's impression. In such circumstances, a negotiated solution becomes less attainable - the parties' differences of opinion over their shares of the pie make them unable to increase the size of the total pie. Moreover, the court battle contributed to considerable hostility between Tyson and IBP management. Finally, Tyson management may have had a vested interest in declining a merger if it was not required to merge. Tyson management was already subject to question for having decided to purchase IBP and then trying to exit the agreement. To subsequently attempt to acquire IBP again after a victory at trial or a loss with a damages award remedy (even at a different price) would have subjected Tyson management to considerable criticism. Similarly, IBP management might have been reluctant to accept a new merger agreement with their adversaries in court without a mandate to do so. These complexities resulting from a bilateral monopoly between Tyson and IBP might have prevented an efficient merger from going forward outside a mandate. ${ }^{59}$

\footnotetext{
${ }^{58}$ See, e.g., Herbert Hovenkamp, Rationality in Law and Economics, 60 Geo. Wash. L. Rev. 293, 307 (1992) (arguing that "bilateral monopoly markets are inherently inefficient and prone to produce much bargaining and failed transactions").

${ }^{59}$ Tyson was a family-controlled company involving two generations of the Tyson family. Don Tyson controlled many of the shares of the company and was very influential with the board of directors, while his son, John, was Tyson's CEO. Don Tyson was against the IBP aquisition, while John was in favor. See $I B P, 789$ A.2d at 23, 40. Because of Don's influence, Tyson, Inc. sought to disentangle the merger. Once the merger was compelled, however, John's day-to-day control over the company raised the probability that the merger would not fall victim to lingering bitterness.
} 
Specific performance, of course, also raises the probability of an inefficient merger going forward. It is extremely unlikely, however, that IBP management would request specific performance rather than damages if specific performance were undesirable. Specific performance raised the distinct possibility that Tyson management would fire IBP management upon acquiring IBP. It is unlikely that IBP management would risk this possibility if performance would be inefficient or damages fully compensatory. In addition, Tyson's failure to mount a forceful argument against specific performance implies that specific performance did not introduce a strong possibility of overperformance. The market's positive reaction to specific performance confirms that overperformance was not a salient concern.

\section{B. Evidence from the Allegheny-DQE MAC Litigation}

The IBP-Tyson litigation may be a unique event. To explore whether these results are anomalous, I examine another MAC-related litigation that occurred between DQE, Inc. (DQE) and Allegheny Energy, Inc. (Allegheny), two publicly traded Pennsylvania electric utilities. ${ }^{60}$ After DQE and Allegheny agreed to merge, some unfavorable regulatory rulings significantly reduced Allegheny's value. DQE invoked the MAC clause of the merger agreement and terminated the deal. Allegheny sued. Allegheny requested a specific performance remedy and a preliminary injunction requiring the merger to go forward. In an unpublished opinion, a federal district court denied Allegheny's preliminary injunction motion, finding that damages would be an adequate remedy and that therefore a preliminary injunction was not warranted. ${ }^{61}$

Allegheny appealed. The Third Circuit remanded the district court's decision, finding that damages would be an inadequate remedy for Allegheny, and instructed the district court to evaluate other "factors" to determine whether a preliminary injunction was warranted. ${ }^{62}$ The Third

\footnotetext{
${ }^{60}$ See Allegheny Energy, Inc. v. DQE, Inc., 171 F.3d 151 (1999). See also Joseph Slobodzian, Business Watch, Nat'l L.J., March 29, 1999, at B2.

${ }^{61}$ See Allegheny Energy, 171 F.3d at 157.

${ }^{62}$ The Third Circuit applies a four-factor test in deciding whether to grant a preliminary injunction. The four factors are: "(1) whether the movant has shown a reasonable probability of success on the merits; (2) whether the movant will be irreparably injured by denial of the relief; (3) whether granting preliminary relief will result in even greater harm to the nonmoving party;
} 
Circuit's decision thus raised the probability of a specific performance remedy. Note, however, that the Third Circuit's decision did not offer a great deal of information regarding the eventual victor of the MAC clause litigation, as it was specifically directed toward remedies. Consequently, it is not surprising that the magnitudes of the changes in the individual and combined values as a result of the decision are considerably smaller than in $I B P$. In a later trial, the district court found that DQE had properly invoked the MAC clause to terminate the merger agreement. ${ }^{63}$ The Third Circuit affirmed this decision. ${ }^{64}$ These decisions lowered the probability of a merger, since they required a renegotiation of terms before the merger could go forward.

Table 2 presents the stock market response to important events in this litigation. Table 2 should be interpreted cautiously. The magnitudes of the changes in value caused by litigation events are considerably smaller than those in $I B P$. In addition, the direction of the effects of some of the changes is surprising. For example, DQE's value shrinks after some decisions that appear to favor DQE over Allegheny. This suggests that the market anticipated the decisions to a much greater degree than in IBP. As a result, the statistical significance of these results is considerably lower than the results presented in Table 1.

Nevertheless, the results in Table 2 are consistent with the notion that the DQE-Allegheny merger was a value-enhancing merger that was more likely to occur with specific performance. The Third Circuit decision stating that damages were an inadequate remedy raised the probability of a specific performance remedy. The market responded positively to this ruling (Table 2 , Row 1 ), with the combined value of the two companies going up by 0.65 percent (although the gains in value were not sustained over a three-day window). The market response to the district and circuit court decisions in favor of DQE (Table 2, Rows 2 and 3), which reduced the probability of a merger, were generally either neutral or negative. In particular, the market initially responded quite negatively to the Third Circuit's opinion affirming

and (4) whether granting the preliminary relief will be in the public interest." Allegheny Energy, 171 F.3d at 157 (internal citations omitted). The district court decided on the basis of Factor 2, and the Third Circuit instructed the district court to weigh the other factors as well.

${ }^{63}$ See Allegheny Energy, 74 F. Supp. 2d 482.

${ }^{64}$ See Allegheny Energy, 216 F.3d 1075. 
Table 2: Stock Price Effects of Allegheny-DQE Litigation Events

\begin{tabular}{|c|c|c|c|c|c|c|}
\hline \multirow[b]{2}{*}{ Event } & \multicolumn{3}{|c|}{$\begin{array}{l}\text { 1-Day Abnormal Return } \\
\text { Expressed as a Percentage of } \\
\text { Starting Value (Standard } \\
\text { Error in Parentheses) }\end{array}$} & \multicolumn{3}{|c|}{$\begin{array}{l}\text { 3-Day Abnormal Return } \\
\text { Expressed as a Percentage of } \\
\text { Starting Value (Standard } \\
\text { Error in Parentheses) }\end{array}$} \\
\hline & $D Q E$ & Allegheny & $\begin{array}{l}\text { Combined } \\
\text { Value }\end{array}$ & $D Q E$ & Allegheny & $\begin{array}{c}\text { Combined } \\
\text { Value }\end{array}$ \\
\hline $\begin{array}{l}\text { 1. Third Circuit opinion } \\
\text { supporting specific } \\
\text { performance }\end{array}$ & $\begin{array}{r}0.44 \\
(1.1)\end{array}$ & $\begin{array}{r}0.81 \\
(1.2)\end{array}$ & $\begin{array}{c}0.65 \\
(0.95)\end{array}$ & $\begin{array}{l}-1.9 \\
(3.3)\end{array}$ & $\begin{array}{r}0.37 \\
(3.6)\end{array}$ & $\begin{array}{r}-0.67 \\
(2.8)\end{array}$ \\
\hline $\begin{array}{l}\text { 2. District court opinion in } \\
\text { favor of } D Q E\end{array}$ & $\begin{array}{c}0.64 \\
(1.1)\end{array}$ & $\begin{array}{r}0.13 \\
(1.2)\end{array}$ & $\begin{array}{c}0.37 \\
(0.95)\end{array}$ & $\begin{array}{l}-1.6 \\
(3.3)\end{array}$ & $\begin{array}{l}-1.4 \\
(3.6)\end{array}$ & $\begin{array}{l}-1.5 \\
(2.8)\end{array}$ \\
\hline $\begin{array}{l}\text { 3. Third Circuit affirmation } \\
\text { of district court }\end{array}$ & $\begin{array}{l}-1.4 \\
(1.1)\end{array}$ & $\begin{array}{l}-2.5^{*} \\
(1.2)\end{array}$ & $\begin{array}{l}-2.0^{*} \\
(0.95)\end{array}$ & $\begin{array}{l}-0.3 \\
(3.3)\end{array}$ & $\begin{array}{l}1.5 \\
(3.6)\end{array}$ & $\begin{array}{l}0.6 \\
(2.8)\end{array}$ \\
\hline
\end{tabular}

NoTE: Each cell in the table presents the "abnormal" percentage change in stock market value (as a percentage of initial value) of Allegheny, DQE, or the combined value of Allegheny + $\mathrm{DQE}$ on the event dates listed in the first cell of each row. The first group of numerical cells in each row presents the abnormal return on the first day after the event. The second group of numerical cells gives the abnormal return three days after the event. The standard error of each estimate is presented in parentheses below the estimate. The abnormal returns and standard errors are estimated using the "market model" described in Bhagat and Romano I (see note 46). An asterisk indicates that the estimate is significant at the 95 percent level.

the district's court's decision in favor of DQE. Again, these results are broadly consistent with the notion that the merger was efficient. Decisions that lowered the probability of a merger without extensive negotiations lowered (or did not change) the combined value of the companies, suggesting that a merger was efficient. At the very least, there is no evidence in the DQEAllegheny litigation to suggest that specific performance was inefficient.

\section{CONCLUSIONS AND INTERPRETATION}

Several tentative conclusions follow from the results presented here. Of course, all these conclusions must be treated with the appropriate "grain of salt" -one or two examples cannot prove anything. Nevertheless, one or two examples are better than none.

The IBP-Tyson conflict sheds light on the revised UCC's provisions regarding the stipulation of specific performance by contract. When the parties stipulate specific performance, the parties must consider the risk allocation and risk of underperformance entailed by the common-law prefer- 
ence for damages as inferior to the risks of overperformance caused by specific performance. The market's positive response to the IBP verdict following Tyson's failure to mount a forceful case against specific performance strongly suggests that an articulated preference for specific performance should be respected because it is efficient. The revised UCC's provision for specific performance should be applauded.

The positive market responses following the surprise pro-specificperformance rulings in $I B P$ and Allegheny suggest that specific performance remedies are particularly appropriate to MAC clause litigations. As noted above, there are reasons to believe that MAC clauses create unusually high risks of underperformance. The event studies confirm that the market was concerned about underperformance. To the extent that IBP and Allegheny are typical MAC-clause litigations, these results suggest that courts should be particularly willing to jettison the common-law preference for damages when considering remedies for improper breaches of merger agreements

Finally, the contrast between the positive market response to the specific performance award in $I B P$ and the negative market responses to damages awards suggests that the general common-law preference for damages over specific performance may be misguided. Neither remedy is obviously better from a theoretical perspective. Instead, the choice of remedies should be an empirical one. In IBP, the market expected a damages remedy. When the market learned of specific performance, it responded positively. This suggests that, at least in some contexts, the market expects courts to grant damages remedies when specific performance is efficient. In other words, the law may not be providing the efficient balance between damages and specific performance remedies.

More empirical research regarding remedies is necessary to determine if these results are robust. Ideally, each class of contract disputes will have its own empirical investigation of the relative efficiency of both remedies. If the empirical evidence consistently favors specific performance across many different classes of contract disputes, a change in the default remedy may be justified. 
